\title{
Subacute cutaneous lupus erythematosus observed with ciprofloxacin
}

\author{
Andrew J Newman, Dustin Mullens, Christine C Lin, Jason Barr
}

Dermatology Residency, Affiliated Dermatology, Scottsdale, Arizona, USA

Correspondence to Dr Andrew J Newman, anewman@affderm.com

Accepted 1 December 2018

\section{A Check for updates}

(c) BMJ Publishing Group Limited 2018. No commercial re-use. See rights and permissions. Published by BMJ.

To cite: Newman $A J$ Mullens D, Lin CC, et al. BMJ Case Rep 2018;11:e227707. doi:10.1136/bcr-2018227707

\section{DESCRIPTION}

A 46-year-old man with a history of prostatitis treated with ciprofloxacin presented with a mildly irritating rash. The rash started 10-12 days after his initiating the ciprofloxacin. The patient had also embarked on a hike through the palm springs desert of Southern California 2 days leading up to the onset of the rash. He denied having any bug bites. He also denied any systemic symptoms such as joint pains, muscle aches, oral or nasal ulcers. $\mathrm{He}$ was on no other medicines prior to initiating ciprofloxacin. Examination revealed many erythematous crescent-shaped plaques without induration and without scale distributed over mainly sun-exposed areas of his body including the chest, and bilateral upper extremities and bilateral lower extremities, excluding the palms and soles (figure 1). Clinically, subacute cutaneous lupus erythematosus (SCLE) was suspected. The differential diagnosis includes other annular papulosquamous conditions including granuloma annulare and tinea corporis. Antinuclear antibody (ANA) and Sjogren syndrome antibody-A (SSA) were the only significant positive serology. Blood work including a complete blood count, complete metabolic profile, C3 and C4 were within normal limits. Two $4 \mathrm{~mm}$ punch biopsies were performed and the H\&E stain revealed a vacuolar interface dermatitis with superficial cellular infiltrates composed of mainly lymphocytes plus sparse plasma cells. Direct immunofluorescence revealed epidermal IgG antibodies. Given the clinical morphology, the positive ANA and SSA serology, the lack of systemic symptoms, plus the resulting histopathology, the patient's condition was most consistent with SCLE.

The authors believe that the ciprofloxacin likely provoked the SCLE, since the timing of this SCLE rash was well correlated with the medication

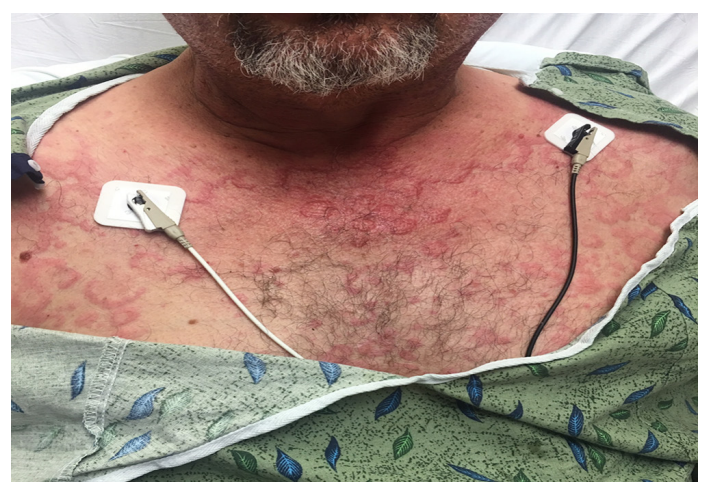

Figure 1 Erythematous crescent-shaped plaques without induration nor scale over the chest. initiation (following 10-12 days after the initiation of ciprofloxacin). No other medication was being used by the patient, eliminating any confounding medications. Importantly, the patient had discontinued ciprofloxacin and initiated medium potency topical corticosteroids, and the rash had completely resolved by the patient's 4-week follow-up. The sunlight that the patient was exposed to during his desert hike was likely an important contributor to the skin eruption. As with any lupus-related skin eruption, sunlight is almost always part of the equation. However, the authors think that the sun exposure alone could not explain the SCLE in this case. After all, the patient is in his middle age and he has lived with a high ultraviolet (UV) radiation index within the Phoenix Valley of Arizona his entire life.

Drug-induced SCLE is the most common form of drug-induced lupus erythematosus, and these conditions are thought to be independent of their idiopathic lupus syndrome counterparts. ${ }^{1}$ Drug-induced SCLE has been observed with the use of multiple medication classes, most commonly antihypertensives and antifungals. ${ }^{2}$ Norfloxacin has been reported to be associated with SCLE with erythema multiforme-like lesions. ${ }^{3}$ Ciprofloxacin has been reported to provoke a systemic lupus erythematosus (SLE)-like flare in multiple patients with SLE, ${ }^{4}$ but it has not been reported to cause drug-induced SCLE. This case strongly suggests that ciprofloxacin may cause drug-induced SCLE. Future ciprofloxacin-induced SCLE episodes are to be expected if the patient was to receive ciprofloxacin again, and this patient should have ciprofloxacin noted to cause SCLE in his list of allergies for future medical encounters. Interestingly, most fluoroquinolones cross-react in immediate-type hypersensitivities, with an exception being moxifloxacin. ${ }^{5}$ However, drug-induced SCLE is not an immediate-type hypersensitivity. Accordingly, the authors of this manuscript find it difficult to anticipate whether the patient would experience drug-induced SCLE from alternative fluoroquinolones.

\section{Learning points}

Drug-induced subacute cutaneous lupus erythematosus (SCLE) is independent of its idiopathic SCLE counterpart.

- Drug-induced SCLE is often due to antihypertensives or antifungals, although many other drugs have been implicated.

- Ciprofloxacin may cause drug-induced SCLE. 
Acknowledgements We thank the faculty and staff of Honor Health and Affiliated Dermatology of Scottsdale, Arizona for their continued support.

Contributors AJN created the case text and performed a literature review for the manuscript. DM created the text for the discussion section of the manuscript. CL provided complete edits for the entire manuscript. JB acted as a dermatology consult to maintain the accuracy of the technical content of the manuscript.

Funding The authors have not declared a specific grant for this research from any funding agency in the public, commercial or not-for-profit sectors.

Competing interests None declared.

Patient consent for publication Obtained.

Provenance and peer review Not commissioned; externally peer reviewed.

\section{REFERENCES}

1 Marzano AV, Tavecchio S, Menicanti C, et al. Drug-induced lupus erythematosus. G Ital Dermatol Venereol 2014;149:301-9.

2 Lowe G, Henderson CL, Grau RH, et al. A systematic review of drug-induced subacute cutaneous lupus erythematosus. Br J Dermatol 2011;97:465-72.

3 Baroni A, Piccolo V, Russo T, et al. Norfloxacin-induced subacute cutaneous lupus with erythema multiforme-like lesions: the enigma of the Rowell syndrome. J Dtsch Dermatol Ges 2014:12:1039-42.

4 Mysler E, Paget SA, Kimberly R. Ciprofloxacin reactions mimicking lupus flares. Arthritis Rheum 1994:37:1112-3.

5 González I, Lobera T, Blasco A, et al. Immediate hypersensitivity to quinolones: moxifloxacin cross-reactivity. I Investig Allergol Clin Immunol 2005;15:146-9.

Copyright 2018 BMJ Publishing Group. All rights reserved. For permission to reuse any of this content visit

https://www.bmj.com/company/products-services/rights-and-licensing/permissions/

BMJ Case Report Fellows may re-use this article for personal use and teaching without any further permission.

Become a Fellow of BMJ Case Reports today and you can:

- Submit as many cases as you like

- Enjoy fast sympathetic peer review and rapid publication of accepted articles

- Access all the published articles

- Re-use any of the published material for personal use and teaching without further permission

For information on Institutional Fellowships contact consortiasales@bmjgroup.com

Visit casereports.bmj.com for more articles like this and to become a Fellow 